\title{
PP4RI Accelerates Cell Growth and Proliferation in HepG2 Hepatocellular Carcinoma [Expression of Concern]
}

\author{
Wu G, Ma Z, Qian J, Liu B. Onco Targets Ther. \\ 2015;8:2067-2074.
}

The Editor and Publisher of OncoTargets and Therapy wish to issue an Expression of Concern for the published article.

Questions about the scientific integrity of the articles content were brought to the Editor and Publisher's atten- tion. Despite reaching out to the authors requesting information that would confirm the article's integrity, the authors have not responded to our queries within the requested timeframe. Therefore, while we continue to work through the issues raised, we advise readers to interpret the information presented in this article with due caution.

\section{Publish your work in this journal}

OncoTargets and Therapy is an international, peer-reviewed, open access journal focusing on the pathological basis of all cancers, potential targets for therapy and treatment protocols employed to improve the management of cancer patients. The journal also focuses on the impact of management programs and new therapeutic agents and protocols on patient perspectives such as quality of life, adherence and satisfaction. The manuscript management system is completely online and includes a very quick and fair peer-review system, which is all easy to use. Visit http://www.dovepress.com/ testimonials.php to read real quotes from published authors. 